\title{
Pengaruh Internal Control, Volatilitas Saham, dan Volume Perdagangan Terhadap Bid-Ask Spread Pada Perusahaan Yang Terdaftar Dalam Indeks LQ45 Tahun 2011-2015
}

\author{
Aida Yulia, Ikramaturrabiah \\ Universitas Syiah Kuala, Aceh, Indonesia
}

\begin{abstract}
The purpose of this study is to examine the effect of internal control, stock volatility, and trading volume on bid-ask spread of companies listed in LQ45 index in the period of 2011 to 2015. Dependent variable used in this study is bid-ask spread, while independent variables used in this study are internal control, stock volatility, and trading volume. By using purposive sampling method, from 45 companies listed in LQ45 index, 16 companies are choosed as the sample in this study. The type of data used in this study is secondary data which are annual report and ICamel. Data is analyzed by statistical analysis using a multiple regression analysis. Then data is processed by statistical package for social science (SPSS) 20. The results of this study show that internal control, stock volatility, and trading volume have simultaneously effect on bid-ask spread. Internal control and stock volatility have significant positive on bid-ask spread, while trading volume have significant negative on bid-ask spread.
\end{abstract}

Keywords. internal control; stock volatility; trading volume; spread bid-ask.

Abstrak
Tujuan dari penelitian ini adalah untuk menguji pengaruh pengendalian internal, volatilitas saham, dan volume perdagangan terhadap bid-ask spread perusahaan yang terdaftar dalam indeks LQ45 pada periode 2011 hingga 2015. Variabel dependen yang digunakan dalam penelitian ini adalah bid-ask spread, sedangkan variabel independen yang digunakan dalam penelitian ini adalah pengendalian internal, volatilitas saham, dan volume perdagangan. Dengan menggunakan metode purposive sampling, dari 45 perusahaan yang terdaftar dalam indeks LQ45, 16 perusahaan dipilih sebagai sampel dalam penelitian ini. Jenis data yang digunakan dalam penelitian ini adalah data sekunder yaitu laporan tahunan dan ICamel. Data dianalisis dengan analisis statistik menggunakan analisis regresi berganda. Kemudian data diproses oleh paket statistik untuk ilmu sosial (SPSS) 20. Hasil penelitian ini menunjukkan bahwa kontrol internal, volatilitas saham, dan volume perdagangan secara simultan berpengaruh pada bid-ask spread. Kontrol internal dan volatilitas saham berpengaruh positif signifikan pada bid-ask spread, sedangkan volume perdagangan memiliki negatif signifikan pada spread bid-ask.

Kata kunci. pengendalian internal; volatilitas saham; volume perdagangan; spread bid-ask.

Corresponding author. Email. aidayulia@unsyiah.ac.id

How to cite this article. Yulia, A., \& Ikramaturrabiah. (2018). Pengaruh Internal Control , Volatilitas Saham , dan Volume Perdagangan Terhadap Bid-Ask Spread Pada Perusahaan Yang Terdaftar Dalam Indeks LQ45 Tahun 2011-2015. Jurnal Pendidikan Akuntansi Dan Keuangan, 5(1), 1-10. Retrieved from http://ejournal.upi.edu/index.php/JPAK/article/view/15826

History of article. Received: Agustus 2017, Revision: November 2017, Published: Januari 2018

\section{Pendahuluan}

Pasar modal merupakan suatu sarana dimana surat berharga-surat berharga yang berjangka panjang diperjualbelikan. Dalam pengertian ini pasar modal memiliki tujuan normatif untuk mencapai keuntungan yang optimal. Namun demikian, sebagai salah satu pelaku ekonomi nasional pasar modal memiliki fungsi intermediasi yaitu menjembatani antara pihak yang memerlukan 
atau membutuhkan modal (manajemen perusahaan) dengan pihak yang memiliki kelebihan modal (investor) (Sartono, 2010:23). Pasar modal memiliki dua fungsi, yaitu fungsi finansial dan fungsi ekonomi. Fungsi finansial berarti pasar modal merupakan sebuah wadah untuk meningkatkan kesejahteraan pemilik modal melalui pembagian hasil (dividen) yang merupakan kompensasi atas dana yang telah ditanamnya. Sedangkan fungsi ekonomi berarti pasar modal memiliki kemampuan untuk menyalurkan dana secara efektif dan efisien dari pemilik modal kepada pihak yang membutuhkan (Napitupulu dan Syahyunan, 2013).

Kondisi pasar modal penuh dengan ketidakpastian yang dapat mengakibatkan timbulnya risiko atas investasi yang akan dihadapi oleh para pelaku pasar modal. Untuk dapat melakukan investasi dengan tepat maka seorang investor saham perlu memiliki sejumlah informasi yang berkaitan dengan pergerakan harga saham agar dapat mengambil keputusan saham perusahaan mana yang akan dipilih. Penilaian saham yang menyeluruh dapat meminimalkan risiko sekaligus membantu investor agar dapat memperoleh keuntungan yang wajar dari investasinya tersebut.

Dalam transaksi saham di pasar modal terjadi proses pembelian dan penjualan saham. Proses transaksi tersebut menimbulkan adanya bid price dan ask price. Bid price adalah harga beli tertinggi, sedangkan ask price adalah harga jual terendah. Selisih antara harga pembelian tertinggi dan penjualan terendah ini disebut dengan bid-ask spread.

Pada penelitian ini mengambil 3 faktor yang mempengaruhi bid-ask spread yaitu internal control, volatilitas saham serta volume perdagangan. Faktor tersebut dipilih karena mempunyai pengaruh terhadap bid-ask spread yang masih kontradiktif atau tidak konsisten pada penelitian-penelitian sebelumnya. Selain itu, variabel volatilitas saham dipilih karena masih kurangnya penelitian yang menggunakan variabel tersebut. Kwon (2016) dalam penelitiannya menyebutkan bahwa baru terdapat satu penelitian tentang internal control terhadap bid-ask spread, yaitu hanya penelitian dari dirinya.

Internal control secara luas dapat diartikan sebagai prosedur-prosedur serta proses-proses yang digunakan perusahaan untuk melindungi asset perusahaan, mengolah informasi secara akurat, serta memastikan kepatuhan pada hukum dan peraturan yang berlaku (Reeve et al., 2009:387). Volatilitas saham adalah bagian dari variabilitas total akibat sensitivitas terhadap perubahan pasar yang merupakan risiko sistematis dan tidak dapat dihindari (Lorie, 1985:184). Sedangkan volume perdagangan adalah jumlah saham yang diperdagangkan untuk suatu periode (Kodrat dan Indonanjaya, 2010:13).

Indeks LQ45 menggunakan 45 saham yang terpilih berdasarkan likuiditas perdagangan. Perusahaan yang tercatat dalam indeks LQ45 diperbarui setiap enam bulan sekali (Darmadji dan Fakhruddin, 2001:96). Penyesuaian indeks LQ45 dilakukan pada awal bulan Februari dan Agustus dengan pertimbangan saham-saham yang paling likuid.

Penelitian ini dilakukan untuk membuktikan bagaimana variabel-variabel tersebut mempunyai pengaruh terhadap bidask spread serta ingin menambah referensi mengenai pengaruh volatilitas saham, volume perdagangan dan khususnya internal control terhadap bid-ask spread. Selain itu karena semakin berkembangnya pasar modal dan semakin banyaknya bermunculan para investor-investor baru, maka dibutuhkan pengetahuan para investor tentang pergerakan harga saham agar dapat membuat sebuah keputusan investasi yang dapat menguntungkan.

\section{Landasan Teoritis \\ Pengaruh Internal Control Terhadap Bid- Ask Spread}

Internal control secara luas dapat diartikan sebagai pengendalian terhadap aset perusahaan, mengolah informasi secara akurat dan handal, dan memastikan kepatuhan pada hukum dan peraturan yang berlaku serta memastikan seluruh kinerja berjalan sesuai dengan yang telah direncanakan (Reeve et al., 
2009:387). Pengendalian internal yang baik dapat membantu perusahaan mengarahkan kegiatan operasi yang lebih baik.

Mulyadi (2008:177) dalam bukunya berpendapat tentang internal control sebagai berikut: Jika pengendalian internal akuntansi dirancang dan diterapkan dengan baik oleh manajemen di dalam pengelolaan perusahaannya, maka laporan keuangan yang disajikan kepada pihak yang berkepentingan akan terjamin ketelitiaan dan keandalannya. Sedangkan sistem pengendalian yang lemah akan mengakibatkan kekayaan perusahaan tidak terjamin keamanannya, informasi akuntansi tidak teliti dan tidak andal, efisiensi tidak terjamin dan kebijakan manajemen tidak dapat dipatuhi.

Internal control yang efektif dapat memaksimalkan kinerja perusahaan dan mencegah terjadinya kecurangan. Internal control yang rendah akan mengakibatkan terjadinya salah saji dan juga dapat menyebabkan kecurangan terhadap laporan keuangan. Selain itu akan menyebabkan perbedaan informasi yang didapat antara perusahaan dan pasar sehingga timbul asimetri informasi. Kemudian dari lemahnya internal control tersebut dapat menyebabkan menurunnya keuntungan perusahaan, menurunkan ukuran perusahaan, struktur menjadi lebih kompleks dan tidak menutup kemungkinan akan terjadinya merger atau akuisisi antar perusahaan. Sehingga internal control yang rendah akan menurunkan bidask spread, sedangkan internal control yang tinggi (efektif) dapat meningkatkan bid-ask spread (Kwon, 2016).

\section{Pengaruh Volatilitas Saham Terhadap Bid- Ask Spread}

Volatilitas saham adalah bagian dari variabilitas total akibat sensitivitas terhadap perubahan pasar yang merupakan risiko sistematis dan tidak dapat dihindari (Lorie, 1985:184). Sedangkan menurut Sova (2013) volatilitas saham adalah ukuran ketidakpastian tentang pergerakan harga saham dimasa mendatang. Semakin meningkatnya volatilitas maka berarti kemungkinan akan naik turunnya harga saham juga akan semakin besar. Hashemijoo et al., (2012) berpendapat bahwa volatilitas saham merupakan rata-rata harga saham yang didapat dari pergerakan harga saham.

Volatilitas harga saham cenderung berubah setiap waktu, dengan demikian tingkat keuntungan juga akan berubah setiap saat (Sartono, 2010:362). Volatilitas harga saham yang semakin berfluktuasi, maka semakin tinggi tingkat jual-beli sahamnya. Sebaliknya apabila volatilitas saham relatif stabil, maka tingkat jual-beli saham akan rendah (Sartono, 2010:345).

Volatilitas saham akan meningkat seiring tingginya transaksi terhadap perdagangan saham. Ketika harga-harga bergerak sangat ketat dalam suatu kelompok, maka standar deviasinya menjadi sangat kecil dan ketika pergerakan harga sangat tersebar, maka standar deviasi menjadi relatif besar (Napitupulu dan Syahyunan, 2013). Menurut Copeland dan Galai (1983) mengatakan sehubungan dengan bid-ask spread, ditemukan bahwa volatilitas yang besar, tingkat harga yang lebih tinggi dan volume yang lebih rendah akan meningkatkan bid-ask spread.

\section{Pengaruh Volume Perdagangan Terhadap Bid-Ask Spread}

Volume perdagangan adalah jumlah saham yang diperdagangkan untuk suatu periode (Kodrat dan Indonanjaya, 2010:13). Dengan demikian, volume perdagangan adalah banyaknya jumlah lembar saham yang diperjualbelikan dalam waktu tertentu, baik harian, mingguan, bulanan dan tahunan.

$$
\text { Menurut Husnan }
$$

Kegiatan perdagangan dalam volume yang besar di suatu bursa akan ditafsirkan sebagai tanda pasar membaik. Peningkatan volume perdagangan dibarengi dengan peningkatan harga merupakan gejala yang makin kuat akan kondisi yang membaik. Perdagangan saham yang aktif dapat dilihat dari volume perdagangan yang tinggi. Hal ini dapat menunjukkan bahwa saham tersebut disukai oleh para investor, sehingga saham tersebut dapat dengan mudah diperdagangkan.

Kondisi ini menyebabkan pedagang tidak perlu memegang saham mereka terlalu lama, yang dapat mengakibatkan penurunan biaya kepemilikan saham. Oleh karena itu, semakin cepat perdagangan saham, maka 
semakin besar pula volume perdagangan saham. Menurut Stoll (1997) jika semakin cepat perdagangan suatu saham, maka akan semakin besar volume saham yang diperdagangkan yang akan menyebabkan menurunnya biaya kepemilikan saham dan berarti akan mempersempit nilai bid-ask spread. Beberapa penelitian terdahulu yaitu Widhyawati dan Damayanthi (2015), Mclnish dan Wood (1992), dan Kwon (2016) samasama menunjukkan pengaruh negatif antara volume perdagangan terhadap bid-ask spread.

\section{Hipotesis}

Berdasarkan kerangka pemikiran yang telah dipaparkan sebelumnya, hipotesis penelitian yaitu (1) $\mathrm{H}_{1}$ : Internal Control, Volatilitas Saham, dan Volume Perdagangan berpengaruh terhadap Bid-Ask Spread. (2) $\mathrm{H}_{2}: \quad$ Internal Control berpengaruh terhadap Bid-Ask Spread. (3) $\mathrm{H}_{3}$ : Volatilitas Saham berpengaruh terhadap Bid-Ask Spread. (4) $\mathrm{H}_{4}$ : Volume Perdagangan berpengaruh terhadap Bid-Ask Spread.

\section{Metode Penelitian \\ Desain Penelitian}

Dalam penelitian ini menggunakan studi penelitian pengujian hipotesis. Jenis investigasi dari penelitian ini bersifat studi kausalitas. Tingkat intervensi dalam penelitian ini digunakan tingkat intervensi minimal. Situasi dalam penelitian ini adalah tidak diatur. Unit analisis dalam penelitian ini adalah perusahaan yang tergabung dalam indeks LQ45 secara terus-menerus selama periode pengamatan, yaitu pada tahun 20112015. Data yang dikumpulkan berupa laporan keuangan tahunan dan data yang diperoleh dari ICamel (Indonesian Capital Market Electronic Library). Dalam penelitian ini horizon waktu yang digunakan adalah pooling datalpanel data.

\section{Populasi dan Sampel Penelitian}

Populasi adalah sekumpulan/sekelompok orang, kejadian, atau sesuatu yang menarik peneliti untuk melakukan penelitian dengan memiliki karakteristik tertentu (Sekaran dan Bougie, 2010:262). Populasi yang digunakan dalam penelitian ini adalah perusahaan- perusahaan yang tergabung dalam indeks LQ45 selama tahun 2011-2015.

Pengambilan sampel menggunakan metode purposive sampling dengan tujuan untuk mendapatkan sampel yang diinginkan. Metode purposive sampling adalah metode pengambilan sampel dengan berdasarkan pertimbangan atau kriteria tertentu. Adapun kriteria sampel yang digunakan dalam penelitian ini yaitu (1) Perusahaan yang tergabung dalam indeks LQ45. (2) Perusahaan yang secara terus-menerus tergabung dalam indeks LQ45 pada tahun pengamatan (20112015). (3) Perusahaan yang selalu menerbitkan laporan tahunan pada tahun pengamatan (20112015). (4) Perusahaan yang menerbitkan laporan keuangan dalam nominal rupiah.

Perusahaan yang tergabung dalam indeks LQ45 yang terdaftar di BEI yang telah memenuhi kriteria sampel penelitian adalah sebanyak 16 perusahaan, sehingga observasi penelitian ini selama 5 tahun adalah 80 emiten.

\section{Teknik Pengumpulan Data}

Teknik pengumpulan data dalam penelitian ini dilakukan dengan teknik dokumentasi. Teknik dokumentasi dengan pengumpulan data yang terkait dengan variabel yang diteliti dan tersedia di BEI dan ICamel.

Data yang digunakan dalam penelitian ini adalah data sekunder. Menurut Sekaran dan Bougie (2011:180), data sekunder adalah data yang telah dikumpulkan oleh para peneliti terdahulu, yang diterbitkan, dan tidak perlu dikumpulkan lagi oleh peneliti sekarang. Data yang digunakan adalah laporan keuangan tahunan perusahaan yang tergabung dalam indeks LQ45 secara terus-menerus selama periode 2011-2015. Data tersebut dapat diperoleh dengan mengakses situs resmi Bursa Efek Indonesia yaitu www.idx.co.id. Data untuk variabel bid-ask spread diperoleh dari ICamel.

\section{Operasional Variabel Penelitian Variabel Dependen}

Variabel dependen/terikat merupakan variabel utama yang menjadi faktor yang berlaku dalam suatu investigasi (Sekaran, 2006:116). Variabel ini dipengaruhi oleh 
variabel-variabel lainnya. Variabel dependen dalam penelitian ini adalah bid-ask spread. Bid-ask spread adalah selisih antara bid price dan ask price, dimana bid price merupakan harga tertinggi, sedangkan ask price adalah harga terendah. Bid-ask spread dapat dirumuskan sebagai berikut:

$$
\text { Volume Perdagangan }=\frac{\text { Jumlah Saham yang Diperdagangkan Waktu t }}{\text { Jumlah Saham yang BeredarWaktu t }} \text { Bid }- \text { Ask Spread }=\frac{(\text { Ask Price }- \text { Bid Price })}{(\text { Ask Price }+ \text { Bid Price }) \times 0,5}
$$

Keterangan:

$$
\begin{array}{ll}
\text { Bid-Ask Spread } & =\text { Selisih antara bid price dan ask price } \\
\text { Ask Price } & =\text { Harga jual terendah } \\
\text { Bid Price } & =\text { Harga beli tertinggi }
\end{array}
$$

\section{Variabel Independen \\ Internal Control}

Internal control adalah pengendalian terhadap kinerja dan asset perusahaan guna mencapai tujuan yang diinginkan. Internal control yang efektif dapat meningkatkan keuntungan perusahaan dan dapat menghasilkan informasi yang akurat, sedangkan internal control yang tidak efektif dapat menimbulkan kecurangan-kecurangan yang tidak diinginkan sehingga akan merugikan perusahaan. Perhitungan internal control menggunakan dummy, dimana jika internal control efektif, akan diberikan angka 1 dan jika internal control yang tidak efektif, maka akan diberikan angka 0 .

\section{Volatilitas Saham}

Volatilitas saham merupakan pergerakan naik turunnya harga saham di dalam bursa efek. Volatilitas menjadi penting untuk dipertimbangkan guna pengambilan keputusan investasi yang tepat dan menguntungkan karena berhubungan dengan pergerakan harga saham. Rumus yang digunakan untuk menghitung volatilitas yang diukur dengan standar deviasi menurut Sartono (2010:144) adalah:

$$
\mathrm{SD}=\sqrt{\mathrm{n} \sum_{\mathrm{i}=0}^{\mathrm{n}} \frac{(\mathrm{Xit}-\overline{\mathrm{X}} \mathrm{it})^{2}}{\mathrm{n}}}
$$

\section{Volume Perdagangan}

Volume perdagangan adalah banyaknya saham yang diperdagangkan atau diperjualbelikan dalam waktu tertentu, baik harian, mingguan, bulanan maupun tahunan. Rumus untuk menghitung volume perdagangan menurut Sjahrial (2006:18) adalah:

\section{Metode Analisis}

Metode analisis yang digunakan dalam penelitian ini adalah metode analisis regresi linear berganda meliputi statistik deskriptif, dan uji asumsi klasik.

Rancangan pengujian hipotesis menggunakan Uji koefisien determinasi $\left(\mathrm{R}^{2}\right)$, uji signifikansi simultan (uji statistik F) dan uji signifikansi parameter individual (uji statistik t).

Persamaan regresi yang digunakan dalam penelitian ini adalah sebagai berikut:

$$
\begin{array}{ll}
\mathrm{Y}=\mathrm{a}+\mathrm{b}_{1} \mathrm{X}_{1}+\mathrm{b}_{2} \mathrm{X}_{2}+\mathrm{b}_{3} \mathrm{X}_{3}+\mathrm{e} \\
\text { Keterangan: } & =\text { Bid-Ask Spread } \\
\mathrm{Y} & =\text { Konstanta } \\
\mathrm{a} & =\text { Koefisien Regresi } \\
\mathrm{b}_{1}, \mathrm{~b}_{2}, \mathrm{~b}_{3} & =\text { Internal Control } \\
\mathrm{X}_{1} & =\text { Volatilitas Saham } \\
\mathrm{X}_{2} & =
\end{array}
$$

Perdagangan

e $=$ epsilon (error

term)

\section{Hasil Dan Pembahasan Statistik deskriptif}

Statistik deskriptif menunjukkan jumlah data observasi, nilai terendah, tertinggi, ratarata, dan standar deviasi untuk masingmasing variabel dengan jumlah sampel penelitian yang digunakan sebanyak 80 data

5 | Jurnal Pendidikan Akuntansi dan Keuangan DOI. 10.17509/jpak.v6i1.15826 | http://ejournal.upi.edu/index.php/JPAK 
observasi. Bid-ask spread merupakan variabel dependen dalam penelitian ini, sedangkan variabel independen adalah internal control, volatilitas saham, dan volume perdagangan.

Nilai terendah dari bid-ask spread sebagai variabel dependen adalah 0,000010 atau $0,0010 \%$ dialami oleh London Sumatra Plantation (LSIP) Tbk. pada tahun 2013. Hal ini bermakna bahwa spread harga beli tertinggi dimana dealer bersedia untuk membeli sekuritas dan harga jual terendah dimana dealer bersedia untuk menjual sekuritas tersebut adalah 0,000010. Sedangkan nilai tertinggi dari bid-ask spread adalah 0,087757 atau $8,7757 \%$ dialami oleh Gudang Garam (GGRM) Tbk. pada tahun 2015. Hal ini bermakna bahwa spread harga beli tertinggi dimana dealer bersedia untuk membeli sekuritas dan harga jual terendah dimana dealer bersedia untuk menjual sekuritas tersebut adalah 0,087757 . Nilai ratarata dari bid-ask spread sebesar 0,0124648 atau $1,24648 \%$, artinya spread harga beli tertinggi dimana dealer bersedia untuk membeli sekuritas dan harga jual terendah dimana dealer bersedia untuk menjual sekuritas tersebut adalah 0,0124648. Nilai standard deviation sebesar 0,0195 lebih tinggi dari nilai rata-ratanya sebesar 0,0124 , artinya adalah variasi data bid-ask spread bersifat heterogen, dengan kata lain bid-ask spread mempunyai sebaran yang besar pada perusahaan.

Variabel independen yang pertama adalah IC (internal control) yang pengukurannya menggunakan dummy, dimana internal control yang efektif diberikan angka 1 dan internal control yang tidak efektif diberikan angka 0. Selain itu, penentuan keefektifan internal control juga ditentukan dengan kelengkapan informasi yang disajikan serta hasil dari kinerja keuangan perusahaan. IC dengan nilai terendah adalah 0 dimiliki oleh beberapa perusahaan selama tahun 2011-2015, sedangkan IC tertinggi adalah 1 yang dimiliki oleh sebagian besar perusahaan selama tahun 2011-2015. Nilai rata-rata IC sebesar 0,8125 yang berarti sebagian besar perusahaan memiliki internal control yang efektif, sedangkan nilai standard deviation sebesar
0,39277 berarti lebih rendah dari nilai rataratanya sebesar 0,8125 artinya adalah variasi data IC bersifat homogen.

Variabel independen yang kedua adalah VS (volatilitas saham). Variabel ini menunjukkan fluktuasi naik turunnya harga saham. Fluktuasi harga saham terendah sebesar 5,00 kali dimiliki oleh Lippo Karawaci (LPKR) Tbk. pada tahun 2011 yang berarti pergerakan harga saham stabil, sedangkan yang memiliki fluktuasi harga saham tertinggi yaitu sebesar 5.816 kali dimiliki oleh Gudang Garam (GGRM) Tbk. pada tahun 2014 yang berarti pergerakan naik turunnya harga saham tinggi. Nilai rata-rata VS sebesar 649,97, sedangkan nilai standard deviation sebesar 1034,15 lebih tinggi dari nilai rata-ratanya, artinya adalah variasi data VS bersifat heterogen.

Variabel independen yang ketiga adalah VP (volume perdagangan). Variabel ini menunjukkan banyaknya lembar saham yang diperdagangkan dalam periode tertentu. Nilai VP terendah adalah 0,0310 dimiliki oleh Astra International (ASII) Tbk. pada tahun 2011 yang berarti terdapat 3,1\% lembar saham yang diperdagangkan dari seluruh total saham yang beredar, sedangkan yang memiliki VP tertinggi sebesar 1,26200 dimiliki oleh Bank Mandiri (BMRI) Tbk. pada tahun 2015 yang berarti terdapat 126,2\% lembar saham yang diperdagangkan. Nilai rata-rata VP sebesar 0,327 , sedangkan nilai standard deviation sebesar 0,2383 lebih rendah dari nilai rata-ratanya, artinya adalah variasi data VP bersifat homogen

\section{Hasil pengujian asumsi klasik Uji Normaitas}

Hasil pengujian normalitas data disimpulkan bahwa nilai Asymp. Sig. (2tailed) berdistribusi normal karena nilai Asymp. Sig. (2-tailed) yang didapat mempunyai nilai 0,117 yang berarti lebih besar dari 0,05 . Setelah variabel terdistribusi normal maka data tersebut dapat digunakan untuk menguji statistik lainnya.

\section{Uji Multikolonieritas}

Hasil pengujian multikolonieritas menunjukkan nilai VIF dan tolerance dari masing-masing variabel, yaitu internal 
control, volatilitas saham, dan volume perdagangan. Nilai tolerance untuk ketiga variabel > 0,10 dan nilai VIF < 10 . Berdasarkan hasil tersebut dapat disimpulkan bahwa dalam model regresi yang digunakan terbebas dari multikolonieritas antar variabel independen.

\section{Uji Heteroskedastisitas}

Hasil pengujian heteroskedastisitas menunjukkan ketiga variabel independen (internal control, volatilitas saham, dan volume perdagangan) menunjukkan nilai sig $>0,05$, sehingga dapat dikatakan tidak terjadi heterokedastisitas.

\section{Uji Autokorelasi}

Berdasarkan hasil pengujian menunjukkan bahwa pada tingkat signifikansi $5 \%$ untuk 80 sampel (n) dan 3 variabel bebas (k), nilai $\mathrm{dU}=1,715$ dan $4-\mathrm{dU}=4-$ $1,715=2,285$. Nilai Durbin Watson 2,173 sehingga $1,715<2,173<2,285$, maka dapat disimpulkan bahwa tidak ada autokorelasi positif maupun negatif pada data tersebut.

\section{Rancangan pengujian hipotesis Metode analisi regresi linear berganda}

Persamaan regresi linier berganda yang diperoleh berdasarkan hasil perhitungan statistik seperti yang terlihat pada tabel 4.6 adalah:

\section{$\mathrm{Y}=0,002+0,009+0,000013-0,015+\mathrm{e}$}

Berdasarkan persamaan regresi tersebut dapat diketahui bahwa (1) Konstanta (a) sebesar 0,002. Artinya, jika internal control, volatilitas saham, dan volume perdagangan dianggap konstan, maka besarnya nilai bidask spread pada perusahaan yang terdaftar dalam indeks LQ45 selama periode 20112015 adalah sebesar 0,2\%. (2) Koefisien regresi internal control sebesar 0,009. Artinya setiap kenaikan $100 \%$ internal control akan menaikkan nilai bid-ask spread pada perusahaan yang terdaftar dalam indeks LQ45 selama periode 2011-2015 sebesar $0,9 \%$. (3) Koefisien regresi volatilitas saham sebesar 0,000013. Artinya setiap kenaikan $100 \%$ volatilitas saham akan menaikkan nilai bid-ask spread pada perusahaan yang terdaftar dalam indeks LQ45 selama periode 2011-2015 sebesar 0,0013\%. (4) Koefisien regresi volume perdagangan sebesar $-0,015$. Artinya setiap kenaikan $100 \%$ volume perdagangan akan menurunkan nilai bid-ask spread pada perusahaan yang terdaftar dalam indeks LQ45 selama periode 2011-2015 sebesar $-1,5 \%$.

\section{Uji Signifikansi Simultan (Uji Statistik F)}

Dari uji $\mathrm{F}$ didapat nilai $\mathrm{F}$ sebesar 36,722 dan signifikansi 0,000 yang bermakna bahwa variabel internal control, volatilitas saham, dan volume perdagangan secara bersamasama mempengaruhi bid-ask spread. Dengan demikian, hipotesis pertama $\left(\mathrm{H}_{1}\right)$ yang menyatakan bahwa internal control, volatilitas saham, dan volume perdagangan secara bersama-sama berpengaruh terhadap bid-ask spread dapat diterima.

\section{Uji Signifikansi Individual (Uji Statistik t)}

(1) Variabel internal control $\left(\mathrm{X}_{1}\right)$ memiliki nilai signifikansi $0,017(1,7 \%)$ yang berarti lebih kecil dari 0,05 (5\%). Hal ini menunjukkan bahwa internal control mempunyai pengaruh terhadap bid-ask spread. Dengan demikian, hipotesis kedua $\left(\mathrm{H}_{2}\right)$ yang menyatakan bahwa internal control berpengaruh terhadap bid-ask spread dapat diterima (2) Variabel volatilitas saham $\left(\mathrm{X}_{2}\right)$ memiliki nilai signifikansi 0,000 yang berarti lebih kecil dari 0,05 (5\%). Hal ini menunjukkan bahwa volatilias saham mempunyai pengaruh terhadap bid-ask spread. Dengan demikian, hipotesis ketiga $\left(\mathrm{H}_{3}\right)$ yang menyatakan bahwa volatilitas saham berpengaruh terhadap bid-ask spread dapat diterima. (3) Variabel volume perdagangan $\left(\mathrm{X}_{3}\right)$ memiliki nilai signifikansi $0,019(1,9 \%)$ yang berarti lebih kecil dari 0,05 (5\%). Hal ini menunjukkan bahwa volume perdagangan mempunyai pengaruh terhadap bid-ask spread. Dengan demikian, hipotesis keempat $\left(\mathrm{H}_{4}\right)$ yang menyatakan bahwa volume perdagangan berpengaruh terhadap bid-ask spread diterima.

\section{Koefisien Determinasi $\left(\mathbf{R}^{\mathbf{2}}\right)$}

Nilai $\mathrm{R}^{2}$ diperoleh sebesar 0.592 atau sebesar 59,2\%. Dengan demikian dapat dikatakan bahwa 59,2\% variasi bid-ask spread pada perusahaan yang terdaftar dalam indeks LQ45 pada tahun 2011-2015 disebabkan oleh ketiga variabel independen dalam penelitian ini yaitu internal control, volatilitas saham, dan volume perdagangan, sedangkan 0.408 atau $40,8 \%$ sisanya disebabkan oleh variabel lain yang tidak diteliti dalam penelitian ini. 


\section{Pembahasan Hasil Pengujian Hipotesis Pengaruh Internal Control terhadap Bid- ask Spread}

Berdasarkan hasil pengujian statistik, secara parsial variabel internal control berpengaruh terhadap bid-ask spread pada perusahaan yang terdaftar dalam indeks LQ45 tahun 2011-2015. Hal ini dapat dilihat dari nilai signifikansi internal control yaitu 0.017 $(1,7 \%)$ atau berada di bawah tarif signifikansi 0.05 (5\%). Hubungan positif sebesar 2,446 yang ditunjukkan oleh internal control terhadap bid-ask spread bermakna bahwa jika semakin tinggi internal control dalam suatu perusahaan, maka semakin besar nilai bid-ask spread pada perusahaan tersebut. Internal control yang tinggi akan memaksimalkan kinerja perusahaan sehingga dapat mensejahterakan para pemegang saham.

Hasil penelitian ini sejalan dengan hasil penelitian Kwon (2016) yang melakukan penelitian pada perusahaan yang tercatat dalam SOX Section yang menunjukkan hasil bahwa internal control berpengaruh positif dan signifikan terhadap bid-ask spread.

\section{Pengaruh Volatilitas Saham terhadap Bid- Ask Spread}

Berdasarkan hasil pengujian statistik, secara parsial variabel volatilitas saham berpengaruh terhadap bid-ask spread pada perusahaan yang terdaftar dalam indeks LQ45 selama periode 2011-2015. Hal ini dapat dilihat dari nilai signifikansi volatilitas saham yaitu $0,000(0 \%)$ atau berada di bawah tarif signifikansi $0,05 \quad(5 \%)$. Hubungan positif sebesar 8,815 yang ditunjukkan oleh volatilitas saham terhadap bid-ask spread bermakna bahwa jika semakin tinggi volatilitas saham dalam suatu perusahaan, maka semakin besar nilai bid-ask spread pada perusahaan tersebut. Volatilitas saham yang tinggi akan meningkatkan jual-beli terhadap saham, sedangkan volatilitas yang cenderung stabil akan memyebabkan menurunnya tingkat jual-beli saham.

Hasil penelitian ini sejalan dengan hasil penelitian Adisetia (2013), yang juga melakukan penelitian pada perusahaan LQ45 yang menunjukkan hasil bahwa volatilitas saham berpengaruh secara positif dan signifikan terhadap bid-ask spread.

Pengaruh Volume Perdagangan terhadap Bid-Ask Spread

Berdasarkan hasil pengujian statistik, secara parsial variabel volume perdagangan berpengaruh terhadap bid-ask spread pada perusahaan yang terdaftar dalam indeks LQ45 selama periode 2011-2015. Hal ini dapat dilihat dari nilai signifikansi likuiditas yaitu $0,019(1,9 \%)$ atau berada di bawah tarif signifikansi $0,05(5 \%)$. Hubungan negatif sebesar -2.397 yang ditunjukkan oleh volume perdagangan terhadap bid-ask spread bermakna bahwa jika semakin tinggi volume perdagangan dalam suatu perusahaan, maka semakin kecil nilai bid-ask spread pada perusahaan tersebut. Perusahaan yang mempunyai volume perdagangan tinggi menyebabkan menurunnya biaya kepemilikan saham dan berarti akan mempersempit nilai bid-ask spread.

Hasil penelitian ini sejalan dengan hasil penelitian Kwon (2016), Mclnish dan Wood (1992), dan Widhyawati dan Damayanthi (2015) yang menunjukkan hasil bahwa volume perdagangan berpengaruh secara negatif dan signifikan terhadap bid-ask spread.

\section{Kesimpulan dan Saran \\ Kesimpulan}

Berdasarkan pembahasan hasil penelitian $=$ yang telah dikemukakan sebelumnya, maka dapat disimpulkan bahwa (1) Internal control, volatilitas saham, dan volume perdagangan secara bersama-sama berpengaruh terhadap bid-ask spread pada perusahaan yang terdaftar dalam indeks LQ45 tahun 2011-2015. (2) Internal control berpengaruh positif dan signifikan terhadap bid-ask spread pada perusahaan yang terdaftar dalam indeks LQ45 tahun 2011-2015. (3) Volatilitas saham berpengaruh positif dan signifikan terhadap bid-ask spread pada perusahaan yang terdaftar dalam indeks LQ45 tahun 2011-2015. (4) Volume perdagangan berpengaruh negatif dan signifikan terhadap bidask spread pada perusahaan yang terdaftar dalam indeks LQ45 tahun 2011-2015. 


\section{Keterbatasan Penelitian}

Penelitian ini mempunyai keterbatasanketerbatasan yang dapat dijadikan bahan pertimbangan bagi peneliti selanjutnya sehingga diperoleh hasil yang lebih baik lagi di masa yang akan datang, yaitu (1) Pemilihan variabel independen yang diduga berpengaruh terhadap bid-ask spread hanya melihat tiga faktor saja yaitu internal control, volatilitas saham, dan volume perdagangan. Hal ini memungkinkan terabaikannya faktor-faktor lain yang juga mempengaruhi bid-ask spread. (2) Penelitian ini hanya meneliti pada perusahaan yang terdaftar dalam indeks LQ45 secara terus-menerus pada tahun 2011 sampai dengan 2015, sehingga hasilnya tidak dapat digeneralisasikan untuk seluruh perusahaan yang terdaftar dalam indeks LQ45. (3) Penelitian ini menggunakan data sekunder sehingga tidak memperoleh persepsi dari pihak manajemen perusahaan langsung.

\section{Saran}

Berdasarkan hasil analisis dan kesimpulan penelitian ini, maka dapat dikemukakan saran-saran yaitu : (1) Diharapkan pada penelitian selanjutnya untuk menambahkan beberapa variabel lainnya yang diduga mempengaruhi internal control, seperti leverage, likuiditas, market value, risiko dan lainlain. (2) Penelitian ini hanya dilakukan pada perusahaan yang terdaftar dalam indeks LQ45, untuk penelitian selanjutnya diharapkan dapat memperluas objek penelitian, tidak hanya pada perusahaan LQ45 saja karena memungkinkan ditemukan hasil dan kesimpulan yang berbeda jika dilakukan pada objek yang berbeda. (3) Diharapkan kepada perusahaan yang terdaftar dalam indeks LQ45 untuk dapat meningkatkan pengendalian internalnya, sehingga kinerja perusahaan menjadi lebih baik dan perusahaan dapat menghasilkan laba yang maksimum.

\section{Daftar Pustaka}

Adisetia, Lukman Dwi. 2013. Pengaruh Harga, Volume Perdagangan, dan Volatility Saham Terhadap Bid-Ask Spread Saham Pada Indeks LQ45. Kindai, 9 (4).

Brigham, Sugene F. \& Joel F. Houston. 2009. Dasar-Dasar Manajemen Keuangan. Jakarta: Salemba Empat.

Chandra, Ardha W.K. 2003. Pengaruh Harga Saham, Volume Perdagangan, dan Volatilitas Harga Saham Terhadap
Bid-Ask Spread. Thesis. Semarang: Universitas Diponegoro.

Copeland, Thomas E. \& Dan Galai. 1983. Information Effects on the Bid-Ask Spread. The Journal Of Finance, 3 (5): 1457-1469.

Darmadji, Tjiptono \& Hendy M. Fakhruddin. 2001. Pasar Modal di Indonesia: Pendekatan Tanya Jawab. Jakarta: Salemba Empat.

Firmansyah. 2006. Analisis Volatilitas Harga Kopi Internasional. Jakarta: Usahawan.

Ghozali, Imam. 2011. Aplikasi Analisis Multivariate dengan Program SPSS.

Edisi 6. Semarang: Universitas Diponegoro.

Gitman, Lawrence J. 2000. Principle of Management Finance. Ninth Edition. Addison Wesley.

Halim, Abdul. 2003. Analisis Investasi. Jakarta: Salema Empat.

Hamilton, James L. 1991. The Dealer and Market Concepts of Bid-Ask Spread: A Comparison For Nasdaq Stocks, The Journal of Financial Research, XIV (2).

Hartono, Jogiyanto.2009. Teori Portofolio dan Analisis Investasi. Edisi 6. Yogyakarta: BPFE.

Hashemijoo, Mohammad., Aref Mahdavi A., \& Nejat Younesi. 2012. The Impact of Dividend Policy on Share Price Volatility in the Malaysian Stock Market. Journal Of Business Studies Quarterly, 4 (1).

Hugida, Lydianita. 2011. Analisis FaktorFaktor yang Mempengaruhi Volatilitas Harga Saham (Studi pada Perusahaan yang Terdaftar dalam Indeks LQ45 Periode 2006-2009). Skripsi. Semarang: Universitas Diponegoro.

Husnan, Suad. 2005. Dasar-Dasar Teori Portofolio dan Analisis Sekuritas. Yogyakarta: AMP YKPN.

Ikatan Akuntan Indonesia. 2007. Standar Akuntansi Keuangan. Jakarta: Salemba Empat.

Jones, Charles Parker, 2002. Investments: Analysis and Management. Seventh Edition. United States Of America: 
John Wiley \& Son,Inc.

Khurniaji, Andreas Widhi \& Surya Raharja. 2013. Hubungan Kebijakan Dividen (Dividend Payout Ratio dan Dividend Yield) Terhadap Volatilitas Harga Saham di Perusahaan-Perusahaan yang Terdaftar di Bursa Efek Indonesia. Diponegoro Journal of Accounting, 2 (3).

Kodrat, David Sukardi \& Kurniawan Indonanjaya. 2010. Manajemen Investasi: Pendekatan Teknikal dan Fundamental untuk Analisis Saham. Yogyakarta: Graha Ilmu

Kwon, Shin Hyoung. 2016. The Effect Of Internal Control Problems on the Bid-Ask Spread Under Sox Section 302. Accounting And Finance Research, 5 (1).

Lorie, James H, Peter Dodd, \& Mary Hamilton Kimpton. 1985. The Stock Market: Theories and Evidence. Second edition. Richard D Irwin, Inc.

Mclnish, Thomas H \& Robert A. Wood. 1992. An Analysis of Intraday Patterns in Bid/Ask Spreads For NYSE Stocks. The Journal of Finance, 47 (2): 753-764.

Mulyadi. 2001. Sistem Akuntansi. Edisi 3. Jakarta: Salemba Empat.

Napitupulu, Veronica \& Syahyunan. 2013. Pengaruh Return Saham, Volume Perdagangan dan Volatilitas Harga Saham Terhadap Bid-Ask Spread pada Perusahaan yang Melakukan Stock Split di Bursa Efek Indonesia. Jurnal. Medan: Universitas Sumatera Utara.

Paramita, Febrica Dewi \& Agung Yulianto. 2014. Pengaruh Harga Saham, Volume Perdagangan, Likuiditas dan Leverage Terhadap Bid-Ask Spread (Studi pada Perusahaan Indeks JII di Bursa Efek Indonesia Periode Tahun 2010-2013). Accounting Analysis Journal.

Rahardjo, Anita Ratna. 2004. Analisis FaktorFaktor yang Mempengaruhi BidAsk Spread. Thesis. Semarang: Universitas Diponegoro.
Reeve, James M, et al. 2009. Pengantar Akuntansi Adaptasi Indonesia. Buku 1. Jakarta: Salemba Empat.

Rodoni, Ahmad. \& Othman Yong. 2002. Analisis Investasi \& Teori Portofolio. Jakarta. PT. RajaGrafindo Persada.

Sartono, Agus. 2010. Manajemen Keuangan Teori dan Aplikasi. Edisi 4. Yogyakarta: BPFE.

Sekaran, Uma. 2006. Metodologi Penelitian untuk Bisnis. Buku 1. Edisi 4. Jakarta: Salemba Empat. . 2011. Research Methods for

Business. Jakarta: Salemba Empat.

Sharpe, William F., Gordon J. Alexander, \& Jeffery V. Bailey. 2005. Investasi. Jakarta: PT. INDEKS Kelompok Gramedia

Sjahrial, Dermawan. 2006. Pengantar Manajemen Keuangan. Edisi 2. Jakarta: Mitra Waena Media

Sova, Maya. 2013. Pengaruh Ratio Leverage Terhadap Volatilitas Saham pada Industry Barang Konsumsi di Bursa Efek Indonesia Tahun 2004-2008. E-Journal Widya Ekonomika, 1 (1).

Stoll, Hans R., \& Roger D. Huang. 1997. The Component of the Bid-Ask Spread: A General Approach. The Review of Financial Studies, 10 (4).

Subramanyam, K. R., \& Wild, J. J. 2013. Analisis laporan keuangan. Buku 1 edisi 10. Jakarta: Salemba Empat.

Susilo, Bambang. 2009. Pasar Modal: Mekanisme Perdagangan Saham, Analisis Sekuritas, dan Strategi Investasi di Bursa Efek Indonesia (BEI). Yogyakarta: UPP STIM YKPN

Widhayanti, I Gusti Mas \& I. G. A. Eka Damayanthi. 2015. Pengaruh Trading Volume, Market Value, dan Return Variance pada Bid-Ask Spread. E-Jurnal Akuntansi Universitas Udayana, 10 (3): 763777.

Zulhendry. 2012. Pasar Modal. Yogyakarta: ANDI OFFSE 